\title{
Deployment of Pre-Industrial Autonomous Microbe Sensor in Saudi Arabia's Injection Seawater System
}

\author{
Mohammed A. Al-Moniee ${ }^{1 *}$, Xiangyang Zhu'1, Rikke Markfoged ${ }^{2}$, Aabdullah H. Al-Wadei1, \\ Poul L. Pedersen ${ }^{2}$, Anders K. Tuxen ${ }^{2}$, Fuad I. Al-Nuwaiser ${ }^{1}$, Lone Tang², Tinna Staghøj Roesen², \\ Thomas Lundgaard ${ }^{2}$
}

${ }^{1}$ Saudi Arabian Oil Company (Saudi Aramco), Dhahran, Saudi Arabia

${ }^{2}$ Danish Technological Institute (DTI), Aarhus, Denmark

Email: ^mohammed.moniee@aramco.com

How to cite this paper: Al-Moniee, M.A., Zhu, X.Y., Markfoged, R., Al-Wadei, A.H., Pedersen, P.L., Tuxen, A.K., Al-Nuwaiser, F.I., Tang, L., Roesen, T.S. and Lundgaard, T. (2018) Deployment of Pre-Industrial Autonomous Microbe Sensor in Saudi Arabia's Injection Seawater System. Journal of Sensor Technology, 8, 1-17.

https://doi.org/10.4236/jst.2018.81001

Received: January 22, 2018

Accepted: March 10, 2018

Published: March 13, 2018

Copyright $(9) 2018$ by authors and Scientific Research Publishing Inc. This work is licensed under the Creative Commons Attribution International License (CC BY 4.0).

http://creativecommons.org/licenses/by/4.0/

\begin{abstract}
Microbial growth in water injection systems can lead to many problems, including biofouling, water quality deterioration, injectivity loss, microbial corrosion, and reservoir formation damage. Monitoring of microbial activities is required in any mitigation strategy, enabling operators to apply and adjust countermeasures properly and in due time. In this study, the pre-industrial autonomous microbe sensor (AMS) was constructed with technical improvements from the prototype for increased sensitivity, durability, robustness, and maintainability. The pre-industrial AMS was lab validated, field proven, and deployed at critical locations of seawater injection network for automated detection of microorganisms under the Saudi Arabia's harsh environment. An excellent correlation between AMS measurement data (fluorescence count) and actual count of microbial cell number under microscope was established (coefficient of determination, $\mathrm{R}^{2}>0.99$ ) for converting AMS fluorescence count to cell numbers (cell $\mathrm{mL}^{-1}$ ) in the injection seawater. The pre-industrial AMS only required monthly maintenance with solutions refill, and was able to cope with hot summer months even without protection in an air-conditioned shelter. The study team recommended wider deployment of the online AMS for real-time monitoring of bacteria numbers in the various strategic locations in Saudi Aramco's complex seawater injection network, as an integral component of pipeline corrosion and leak mitigation program.
\end{abstract}

\section{Keywords}

Automated Monitoring, Autonomous Microbe Sensor, Microbial Sensor, DNA Staining, Injection Seawater 


\section{Introduction}

Saudi Arabian Oil Company (Saudi Aramco) has the largest seawater injection system in the world. The growth of microorganisms and the formation of biofilm on the pipeline's inner surfaces and process equipment lead to an array of challenges, including biofouling, water quality deterioration, injectivity loss, reservoir plugging, and microbiologically influenced corrosion (MIC) [1] [2]. A critical cornerstone in an effective mitigation strategy is the routine surveillance of the system microbiology, enabling operators to apply and adjust microbiological countermeasures accordingly.

The microbial number and activity are traditionally monitored with conventional growth methods that require manual sampling and handling. Monitoring the microbial activity with conventional methods in this large system, especially at the remote locations, presents a long-standing challenge to Saudi Aramco. In an attempt to ensure the injection water quality and maintain the integrity of injection pipelines network, Saudi Aramco and the Danish Technological Institute (DTI) embarked on a three-phase project with an overall objective of developing and deploying an online sensing technology for automatic and real-time monitoring of microbial numbers in Saudi Aramco's large injection seawater system.

In the feasibility phase study [3] [4], five single-analyte methods were evaluated in the laboratory setup for the suitability of automation for detection of microbial activity in the Saudi Aramco injection seawater. Staining of cells with DNA binding fluorescent dyes (SYBR Green), followed by quantification of fluorescence signals, was identified as a reliable single-analyte method for automated, online determination of microbial cell numbers in the injection seawater system.

In the subsequent phase, an autonomous microbe sensor (AMS) prototype was constructed, tested, and optimized in the laboratory, followed by a validation in the field for automated detection of microorganisms in the harsh Saudi Arabia desert environment [5]. In the field validation, the AMS prototype was able to monitor and follow the general microbial status in the system, including detection of periods with increased microbial growth or decreased microbial numbers following biocide injection. The infield AMS prototype detection limit was $10^{5}$ cells $/ \mathrm{ml}$.

The objective of the current phase study was to implement the technical improvements identified in the prototype field validation [5], construct two pre-industrial AMS devices, validate and deploy the pre-industrial AMS in Saudi Aramco's seawater injection network. The technical improvements aimed to increase the sensitivity, durability, robustness, and maintainability, while reducing the uncertainties related to AMS operation and function.

\section{Technical Improvements of Pre-Industrial AMS}

The pre-industrial AMS is an instrument that provides an online and real-time detection of total microbial numbers in seawater pipelines. It is provided with a 
flow cell that measures the fluorescence intensity of microorganisms in the seawater sample after mixing with DNA staining dye SYBR Green [6] [7] [8]. The sensor contains all necessary ancillary systems to sample seawater and fluorescence dye, inject them in precise volumes, mix them and dispose them after measurement, to a waste container. The microbial number is derived from the fluorescence intensity through a calibration procedure that can be checked periodically. The calibration procedures involve the fluorescence intensity measurement with AMS, the temperature during measurement and the direct microscopy counting of known concentrations of bacteria dilutions after staining with 4, 6-diamindino-2-phenylindole (DAPI) [9] [10] [11].

The areas for technical improvement and optimization identified in the field testing of the AMS prototype [5] have been incorporated in the design and construction of the pre-industrial AMS. Some of the improvement areas were:

1) Optimization of cleaning procedures: The internal AMS cleaning procedures were optimized to minimize the risk of biofouling and iron precipitation. Alkaline $(\mathrm{NaOH})$ and acid (oxalic acid) cleaning procedures were incorporated into the measurement cycle to prevent the biofouling and formation of iron precipitations in liquid handling components.

2) Incorporation of an internal DNA control: The internal DNA control was used to validate the AMS functionality and compensate the temperature effect on fluorescence counts.

3) Optimization of fluorescence detection procedure and software: The sampling procedure and software were optimized in the pre-industrial AMS to minimize the scattering of data points caused by uneven cell distribution.

4) Sensitivity improvement. The detection limit of pre-industrial sensor was improved by optimizing hardware components (spectrophotometer, optical fiber, and flow cell) and microbial staining and measurement procedures.

5) Incorporation of temperature correction factor. The temperature inside the AMS was measured simultaneously with the fluorescence measurements. The inside temperature and the fluorescence count of internal DNA control were used to develop a temperature compensation factor to compensate the temperature effect on the fluorescence dye.

6) Redesigned user interface: The new software interface, layout and data output allowed data export and automatic plotting and display in remote computer.

\section{Design and Construction of Pre-Industrial AMS}

The design of pre-industrial AMS has incorporated the technical improvement areas identified from AMS prototype. Design changes from the prototype to the pre-industrial AMS are summarized in Table 1.

The pre-industrial AMS consists of three separate modules: hardware module, consumables module, and power module:

1) Hardware module: includes a custom-made flow cell for achieving flow 
Table 1. Design changes from the prototype to the pre-industrial AMS.

\begin{tabular}{|c|c|c|}
\hline Part & Prototype AMS & Pre-industrial AMS \\
\hline Unit layout & Single box & $\begin{array}{l}\text { Three modules: hardware, } \\
\text { consumables, and battery }\end{array}$ \\
\hline $\begin{array}{l}\text { Internal DNA } \\
\text { control }\end{array}$ & N/A & $\begin{array}{l}\text { Synthetic DNA in } \\
\text { ethyleneiaminetetraacetic acid } \\
\text { (EDTA) and ascorbate buffer }\end{array}$ \\
\hline Sample staining & $40 \mathrm{~min}$ at ambient temperature & $13 \mathrm{~min}$ at $60^{\circ} \mathrm{C}$ \\
\hline Flow cell & $\begin{array}{l}\text { Commercially available } \\
\text { flow cell }\end{array}$ & $\begin{array}{l}\text { Custom-built flow cell with minimal } \\
\text { volume and large numerical aperture }\end{array}$ \\
\hline Measurement & $\begin{array}{l}\text { Sample is static when } \\
\text { illuminated }\end{array}$ & $\begin{array}{l}\text { Sample flows slowly when illuminated to } \\
\text { avoid bleaching of dye }\end{array}$ \\
\hline Dye dispensing & Fixed volume & Dedicated syringe pump for dye \\
\hline & & Low limit of detection, LLOD \\
\hline $\begin{array}{l}\text { Lower limit of } \\
\text { field detection }\end{array}$ & $\sim 10^{5}$ & $\begin{array}{c}-\quad \text { AMS 1: } 1.9 \times 10^{4} \text {; AMS 2: } 1.2 \times 10^{4} \\
\text { Low limit of quantification, LLOQ }\end{array}$ \\
\hline & & - $\quad$ AMS 1: $5.0 \times 10^{4} ;$ AMS $2: 3.2 \times 10^{4}$ \\
\hline Cleaning & $\mathrm{NaOH}$ & $\mathrm{NaOH}$ and oxalic acid \\
\hline Power & AC mains & $\begin{array}{l}\text { Battery, charged either by AC } \\
\text { mains or solar panels }\end{array}$ \\
\hline $\begin{array}{l}\text { Remote } \\
\text { communication }\end{array}$ & $\begin{array}{l}\text { Team Viewer through } \\
\text { Saudi Aramco intranet } \\
\text { when AMS is on }\end{array}$ & $\begin{array}{l}\text { Permanent RS-485 connection. Data } \\
\text { retrieval and AMS control through } \\
\text { dedicated software on remote computer }\end{array}$ \\
\hline
\end{tabular}

during quantification, a heating chamber for improved staining conditions and two dedicated pumps. Pump A is for dispensing water sample and cleaning solutions; while Pump B is dedicated for SYBR Green dye distribution.

2) Consumables module: includes four containers for water, oxalic acid, sodium hydroxide and waste.

3) Power module: A $24 \mathrm{~V}$ DC battery pack was chosen as the power supply. The batteries are connected to three solar panels or $230 \mathrm{~V} \mathrm{AC}$ mains power.

The modular design of AMS improves the equipment functionality and durability in the challenging Saudi Arabia dessert environment and operation conditions of seawater injection system [4]. Each of these three modules are mounted in a stainless-steel cabinet and may be stacked with the battery module at the bottom, the consumables module in the middle and the hardware module at the top (Figure 1). The AMS is designed to run on batteries that are charged by solar panels or $230 \mathrm{~V}$ mains power. The AMS device installed in the field is connected to the remote computer through a MODBUS protocol using RS-485 cable. The Lab View application [12] on the remote computer controls the sensor operation, equipment shut down following measurements, and data retrieval.

\section{Performance Assessment}

\subsection{Lab Validation}

After construction of two pre-industrial AMS units, the AMS was thoroughly 
tested and validated in the laboratories at DTI premises. The repeatability and functionality of the units were tested with respect to procedures as well as software. The major improvements in lab validation and their effect on AMS performance are summarized in Table 2.

After implementation of above improvements on AMS units, a correlation of fluorescence signals from AMS and direct counting of microbial cell number

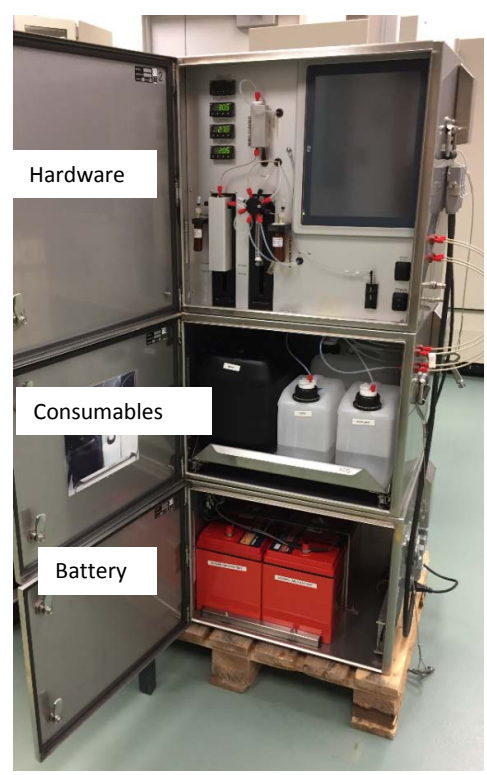

Figure 1. Hardware module, consumables module, and power module of pre-industrial AMS.

Table 2. Major improvements incorporated during the lab validation.

\begin{tabular}{|c|c|}
\hline Improvement & Effect \\
\hline Decrease of Pump A rate to $3 \mathrm{~mL} \cdot \mathrm{min}^{-1}$ & Eliminate air from surroundings into syringe A \\
\hline New loading procedure & Improved mixing of internal control (IC) \\
\hline for internal DNA control & DNA and Milli-Q water \\
\hline $\begin{array}{l}\text { Increased total volume of diluted internal } \\
\text { DNA control to sample volume }\end{array}$ & Improved loading of IC DNA \\
\hline $\begin{array}{l}\text { New dye loading procedure. Dead space in } \\
\text { Pump B valve used as dye dosing volume }\end{array}$ & Accurate dye dosing \\
\hline $\begin{array}{l}\text { Selection of incubation conditions of } \\
\qquad 13 \mathrm{~min} \text { at } 60^{\circ} \mathrm{C}\end{array}$ & Improved staining of cells with SYBR Green I \\
\hline No air is moved through flow cell & Eliminate introduction of air bubbles in flow cell \\
\hline Flow direction of flow cell changed & Remove potential air bubbles in flow cell \\
\hline New flow rate through flow cell & Optimal flow rate for maximum reading \\
\hline $\begin{array}{l}\text { Increased rate of dispensing and aspirating } \\
\text { with Pump A for all non-critical steps }\end{array}$ & $\begin{array}{l}\text { Minimize total AMS measurement cycle time } \\
\text { to } 75 \mathrm{~min}\end{array}$ \\
\hline Incorporated data export function & $\begin{array}{c}\text { For automatic plot of raw and } \\
\text { calibrated readings on graph in Excel }\end{array}$ \\
\hline
\end{tabular}


under microscope after DAPI staining was established (Table 3). The correlation is performed using a series of dilutions of sulfate-reducing bacteria (SRB) enriched from Saudi Aramco injection seawater and diluted in phosphate buffer $(\mathrm{pH} 8,5.5 \% \mathrm{NaCl})$. The correlation is required to convert the data obtained by the AMS, in terms of fluorescence counts, into cell count per volume (cells $\mathrm{mL}^{-1}$ ).

The calibrations show that the AMS units are linear in a wide range of at least two orders of magnitude, with a laboratory detection limit of around $10^{3}$. From the performed calibrations, the AMS units were accepted for field installation, calibration, and validation.

At the end of lab validation, the optimal AMS measurement settings were determined and implemented in both AMS units (Table 4).

Table 3. Laboratory calibration data and equation for AMS1 and AMS2.

\begin{tabular}{|c|c|c|c|c|}
\hline & \multicolumn{2}{|c|}{ AMS1 } & \multicolumn{2}{|c|}{ AMS2 } \\
\hline & $\begin{array}{l}\text { Fluorescence } \\
\text { count (AMS) }\end{array}$ & Cells $\mathrm{mL}^{-1}$ & $\begin{array}{l}\text { Fluorescence } \\
\text { count (AMS) }\end{array}$ & Cells $\mathrm{mL}^{-1}$ \\
\hline $\begin{array}{l}\text { Sterile filtered system } \\
\text { water (blank) }\end{array}$ & $154 \pm 7, \mathrm{n}=3$ & & $98 \pm 3, \mathrm{n}=3$ & \\
\hline LLOD & 167 & $6.0 \times 10^{3}$ & 104 & $8.8 \times 10^{2}$ \\
\hline LLOQ & 188 & $1.6 \times 10^{4}$ & 114 & $2.3 \times 10^{3}$ \\
\hline Regression equation & \multicolumn{2}{|c|}{$473 X-72,788$} & \multicolumn{2}{|c|}{$146 \mathrm{X}-14,265$} \\
\hline Regression, $\mathrm{R}^{2}$ & \multicolumn{2}{|c|}{0.9902} & \multicolumn{2}{|c|}{0.9490} \\
\hline Linear range & \multicolumn{2}{|c|}{$6.4 \times 10^{3}-5.0 \times 10^{6}$} & \multicolumn{2}{|c|}{$1.1 \times 10^{4}-2.4 \times 10^{6}$} \\
\hline
\end{tabular}

LLOD: Lower Limit of Detection; LLOQ: Lower Limit of Quantification.

Table 4. Final settings for one full AMS measurement cycle.

\begin{tabular}{cc}
\hline Improvement & Effect \\
\hline Volume of sample & $4 \mathrm{ml}$ \\
Volume of IC DNA & $\begin{array}{r}\text { ml }(0.1 \mathrm{ml} \text { concentrated IC discarded at first, } \\
\left.0.2 \mathrm{ml} \text { IC in } 3.8 \mathrm{ml} \text { sterile } \mathrm{H}_{2} \mathrm{O}\right)\end{array}$ \\
SYBR Green I & $\begin{array}{c}\text { Diluted } 1: 20 \text { in Dimethyl sulfoxide (DMSO }) . \\
\text { Volume equals to dead space in Pump B }(20 \mu \mathrm{L})\end{array}$ \\
Incubation of sample & $\begin{array}{c}13 \text { min at } 60^{\circ} \mathrm{C} \\
\text { Incubation of IC } \\
\text { Flow rate and time }\end{array}$ \\
Less than one minute at ambient temperature \\
Measurement wavelength interval
\end{tabular}

Fluorescence count

Background reading (auto-fluorescence)

Cleaning
Average of readings every one sec for 180 and $10 \mathrm{sec}$

To be subtracted from sample reading. Fluorescence reading of sample without dye, for correction of any auto-fluorescence of the sample water. Background reading is not subtracted from internal control readings.

Sterile $\mathrm{H}_{2} \mathrm{O}$ and air between sample and IC measurement. Acid, alkaline, sterile water and air at the end of a cycle. No air through the flow cell. 75 min for one full cycle, including washing/cleaning 


\subsection{Field Installation and Calibration}

After laboratory validation at DTI premises, both AMS units were shipped to Saudi Aramco, and tested for functionality and stability after transportation. After functionality check, AMS1 was connected to the side-stream of a 60" shipping line at an injection facility and AMS2 was installed at an injection plant further downstream of AMS1, connecting to a side-stream of 40" seawater pipeline. The seawater flow continuously passes AMS through a bypass connection to the disposal when AMS is not doing the measurement. During the measurement cycle, a fixed volume of seawater sample is taken into the AMS for staining and measurement of microbial cell number. During the field testing and validation, the sensors were programmed to take two measurements a day, with a monthly maintenance for solutions refill. The data were retrieved by the operators in the Control Room.

The fluorescence intensity from a stained sample depends on the amount of DNA present in the sample, which in turn, depends on the cell size and the metabolic status of the cell, as an actively dividing cell contains more DNA than a dying cell [13] [14] [15]. Therefore, the fluorescence intensity from the AMS was re-calibrated in Saudi Aramco with active aerobic heterotrophic bacteria enriched from injection system seawater. A 3-point field calibration was performed on AMS1 and AMS2 using the bacteria dilution series prepared with sterile filtered system water.

The calibration correlates the cell number $\left(\right.$ cell $\left.\mathrm{mL}^{-1}\right)$ of the system water determined by DAPI staining and counting to AMS fluorescence counts from dilution series of the sample measured in the field. A typical DAPI staining for counting microbial cell number under microscope is shown in Figure 2. The results of 3-point field calibration between cell number and fluorescence count is shown in Figure 3.

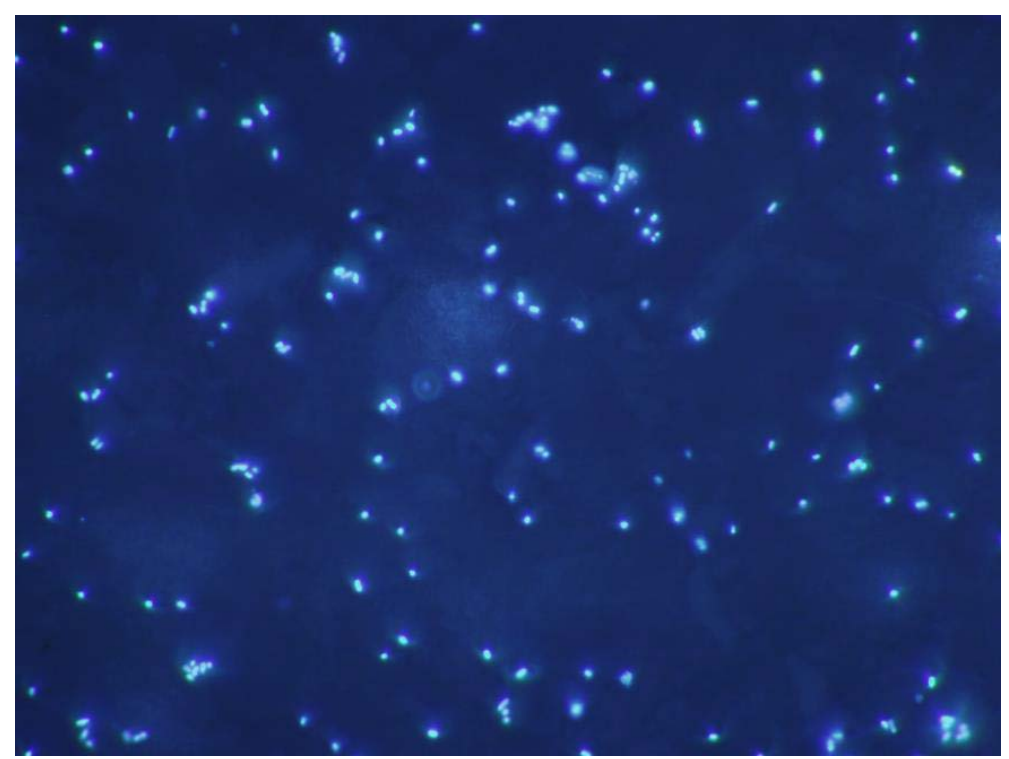

Figure 2. DAPI staining and counting under microscope. 


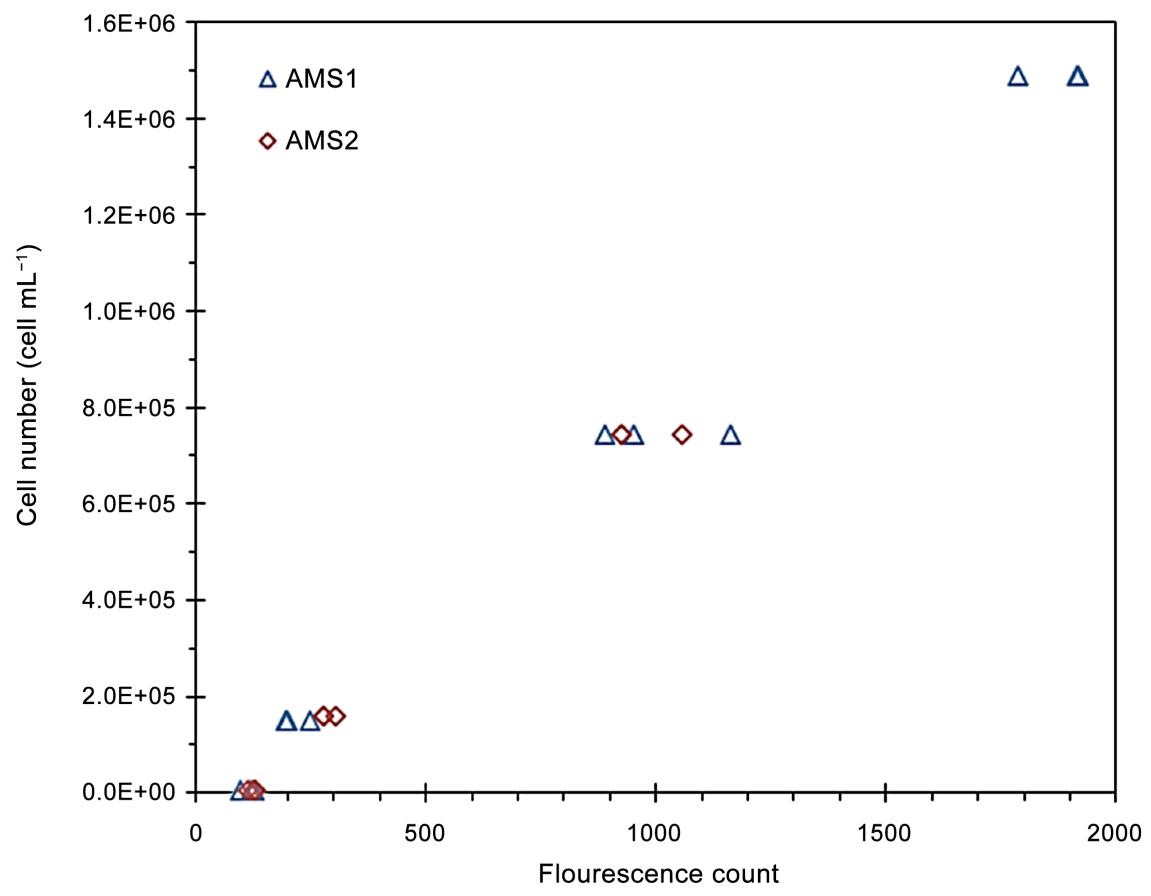

Figure 3. Relation between cell number and fluorescence count of AMS1 (blue) and AMS2 (red) using enrichment culture from the system, diluted in sterile filtered system water. All AMS readings are performed with an AMS interior temperature of $30^{\circ} \mathrm{C}$.

A linear regression between AMS fluorescence measurement and DAPI count for converting AMS fluorescence count to cell numbers in the sample is summarized in Table 5. Compared to the calibration performed in the laboratory, these data show that the fluorescence count relative to the cell number is lower in the field, and therefore the regression equation in the lab at $25^{\circ} \mathrm{C}$ is not recommended for field trial. The field regression equations for each AMS unit were loaded in the specific AMS units, and used for the data conversion from fluorescence count to cell number.

\subsection{Temperature Effect on Fluorescence Intensity}

During the field validation of the AMS units, a tendency of higher fluorescence counts with lower AMS inside temperatures has been observed. A full correlation of all internal DNA control readings shows an exponential decrease in fluorescence with increasing temperature, which fits well with an exponential function with both a vertical and horizontal offset [Figure 4 and Equation (1)].

$$
f(x)=A \times \exp \left[B\left(x-x_{0}\right)\right]+C
$$

where the fitted parameters are $A=2.4 \times 10^{4} \mathrm{~s}^{-1}, B=-0.10^{\circ} \mathrm{C}^{-1}, x_{0}=4.16^{\circ} \mathrm{C}, C=$ $2.49 \times 10^{3} \mathrm{~s}^{-1}$, and $x=$ AMS inside temperature $\left({ }^{\circ} \mathrm{C}\right)$.

The function $f(x)$ between temperature and fluorescence intensity was used to temperature compensate internal control (IC) readings. The compensation is done by multiplying the IC reading with the ratio $f(30) / f(T)$, where 30 is the reference temperature, and $\mathrm{T}$ is the AMS inside temperature of the given data point. 
Table 5. Field calibration data and equation for AMS1 and AMS2.

\begin{tabular}{ccccc}
\hline & \multicolumn{2}{c}{ AMS1 } & \multicolumn{2}{c}{ AMS2 } \\
\cline { 2 - 5 } & $\begin{array}{c}\text { Fluorescence } \\
\text { count (AMS) }\end{array}$ & Cells $\mathrm{mL}^{-1}$ & $\begin{array}{l}\text { Fluorescence } \\
\text { count (AMS) }\end{array}$ & Cells $\mathrm{mL}^{-1}$ \\
\hline $\begin{array}{c}\text { Sterile filtered } \\
\text { system water (blank) }\end{array}$ & $114 \pm 12, \mathrm{n}=3$ & $123 \pm 7, \mathrm{n}=3$ & \\
LLOD & 136 & $1.9 \times 10^{4}$ & 137 & $1.2 \times 10^{4}$ \\
LLOQ & 173 & $5.0 \times 10^{4}$ & 160 & $3.2 \times 10^{4}$ \\
Regression equation & \multicolumn{2}{c}{$843 \mathrm{X}-96,020$} & \multicolumn{2}{c}{$0.9940 \mathrm{X}-107,935$} \\
Regression, $\mathrm{R}^{2}$ & \multicolumn{2}{c}{0.9939} & \multicolumn{2}{c}{} \\
\hline
\end{tabular}

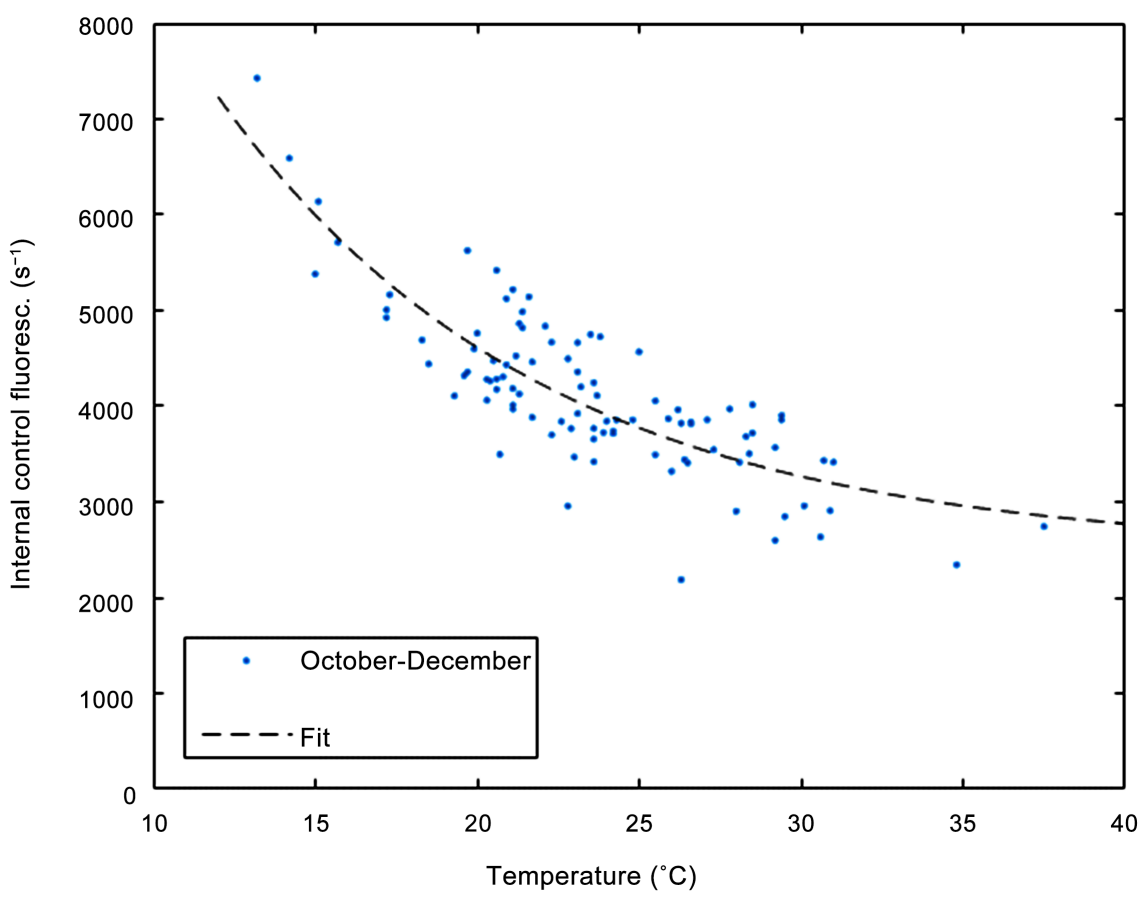

Figure 4. Internal control DNA fluorescence readings versus temperature inside AMS during field readings. October-December data have been fitted with an exponential function with both a vertical and horizontal offset.

The temperature effect on fluorescence intensity is likely related to the molecular structure of SYBR Green I, as the supplier of SYBR Green (Invitrogen) explained that "the temperature effect is likely caused by less rigid bonds in the fluorescent molecule as the atoms become excited and move around." Therefore, the observed temperature response is a direct consequence of the reduced SYBR Green fluorescence at elevated temperatures. In this case, the fluorescence intensity of stained IC DNA or stained cells are equally affected by temperature.

An IC measurement is performed for each AMS run with equal DNA content for each run. As the IC and system water samples are affected equally by temperature, the IC can, besides validating the performance of the AMS unit, also be used for an internal temperature compensation. Figure 5 and Figure 6 showed the raw fluorescence readings and readings after temperature compensation 
from IC DNA and system seawater, respectively.

Other possible causes for the temperature dependency (melting of oligonucleotides DNA and heating of spectrometer) have been considered unlikely. Internal control DNA (a synthetic 55-base pair oligonucleotides with hairpin structure) was tested for the stability at a wide range of temperature. The synthetic DNA in EDTA and ascorbate buffer was found to be stable from $20^{\circ} \mathrm{C}$ to $80{ }^{\circ} \mathrm{C}$ for at least 28 days when stored in a sealed container.
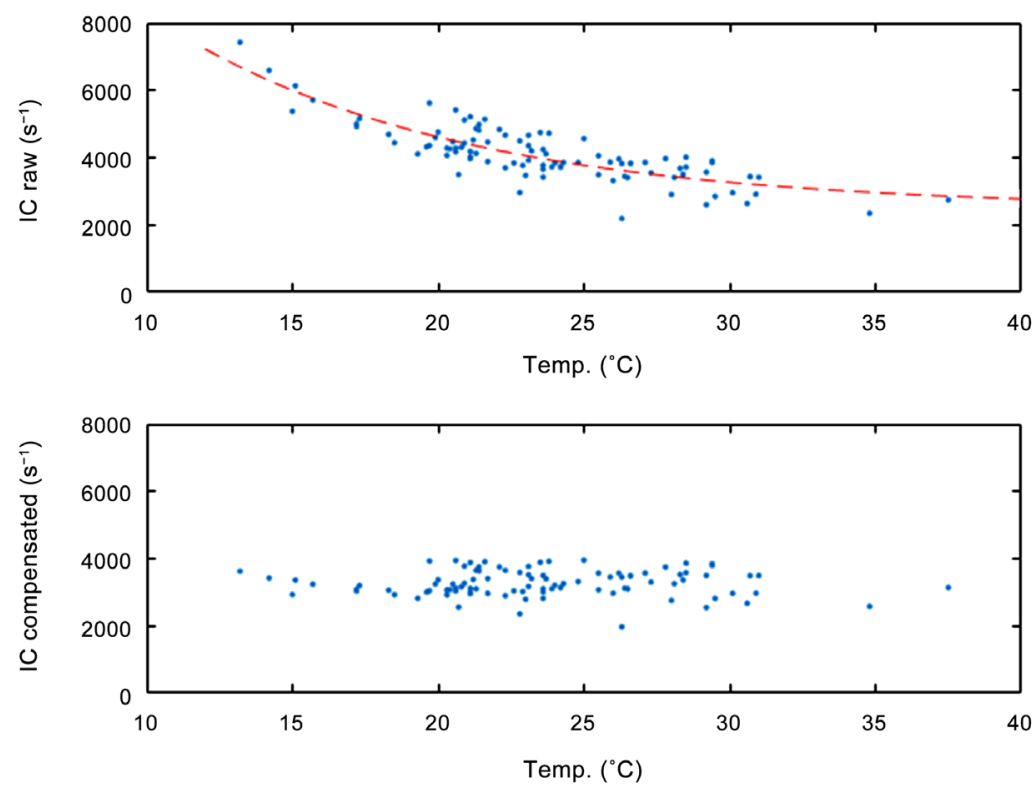

Figure 5. Internal control DNA fluorescence readings (October-December)-raw (top) and temperature compensated (bottom).
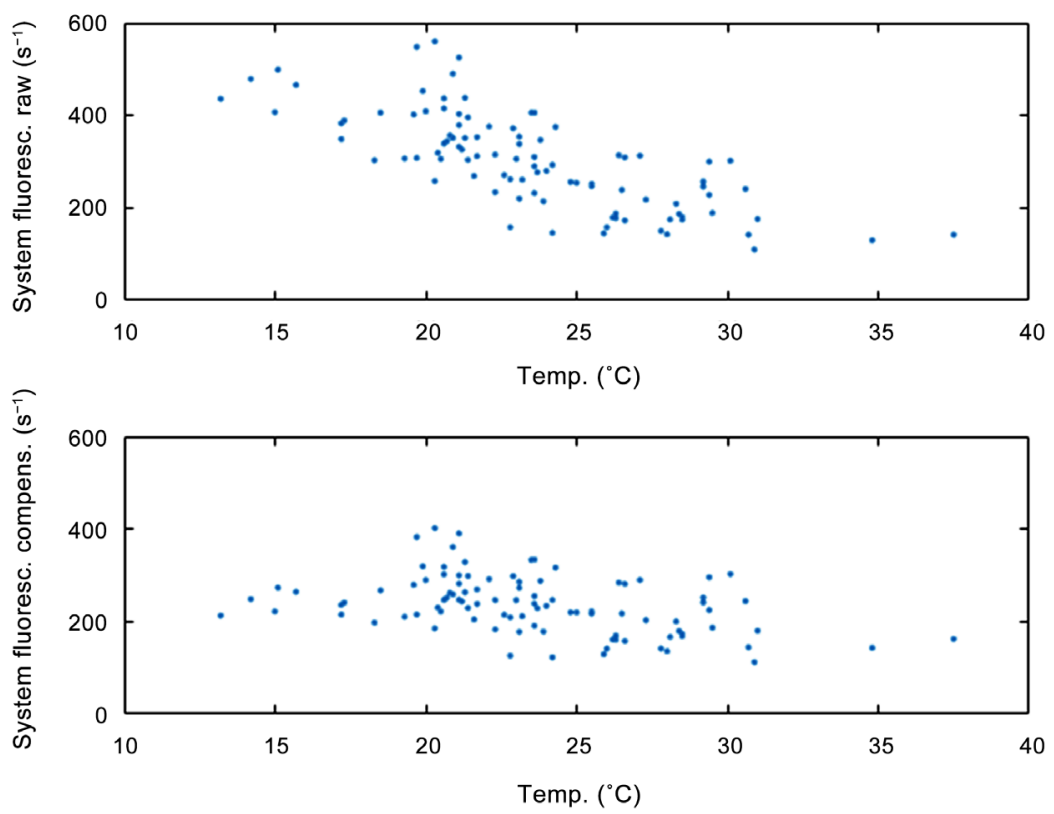

Figure 6. System seawater fluorescence readings (October-December)-raw (top) and temperature compensated (bottom). 
Melting of the double stranded (ds) Oligo DNA (internal control) would result in a lower binding between the SYBR molecule and the DNA, as SYBR Green I only binds to ds DNA [6] [16]. The oligo DNA as well as the internal control buffer have been designed to withstand high temperatures, and based on calculations from the Oligo DNA supplier (Integrated DNA Technologies), the melting temperature $\left(\mathrm{T}_{\mathrm{m}}, 50 \%\right)$ is $73^{\circ} \mathrm{C}$ for the conditions provided from the internal control buffer solution (Figure 7).

The spectrometer must be cooled for proper readings, and cooling has been included in the design of the AMS. To test whether the AMS spectrometer is affected by AMS inside temperature, fluorescein was injected manually into the flow cell at high and low temperatures $\left(40^{\circ} \mathrm{C}\right.$ and $25^{\circ} \mathrm{C}$, respectively). Fluorescein is a dye that emits fluorescent light with excitation and emission spectra comparable to those of SYBR Green when bound to DNA [17]. The effect of AMS inside temperature on spectrometer readings of fluorescein at two concentrations was not detected (data not shown).

\subsection{Field Measurements}

The AMS1 measurement data, from October 2016 to February 2017, on the fluorescence count of the IC DNA and microbial cell number in the seawater are plotted in Figure 8 and Figure 9, respectively. Figure 8 shows that the IC readings are relatively stable in this 4 -month period, after temperature compensation of fluorescence intensity, verifying the stability of both IC DNA and SYBR Green dye, and the functionality of AMS in the field. Figure 9 shows that the majority of the measurements of seawater cell number are above the detection limit. When system water fluorescence count has been temperature compensated, the cell numbers from winter are in the range comparable to fall cell numbers.

Temperature effect on fluorescence intensity is determined to be significant when SYBR Green I dye is used to stain IC DNA and cell DNA in seawater samples. As a result, temperature compensation for all fluorescence counts of both IC DNA and microbial cells is required. The temperature compensation factor was incorporated in the software for converting the raw data to temperature compensated data for data exporting and plotting.

\section{Lessons Learned}

During the field testing and validation, a number of technical challenges have been either encountered or identified, and the solutions have been implemented to address these challenges (Table 6). Among the challenges, the two main threats are the pressure regulator clogging and leakage from the fluid handling system, which are discussed in detail in the following text, to illustrate how the technical challenges have been resolved.

The pre-industrial AMS is equipped with a restrictor to reduce the side-stream pressure from 10 bars to less than 1 bar before water enters the AMS system. The restrictor is equipped with a pressure gauge to monitor inlet pressure. Since the seawater pipeline pressure is much higher, it is important that 


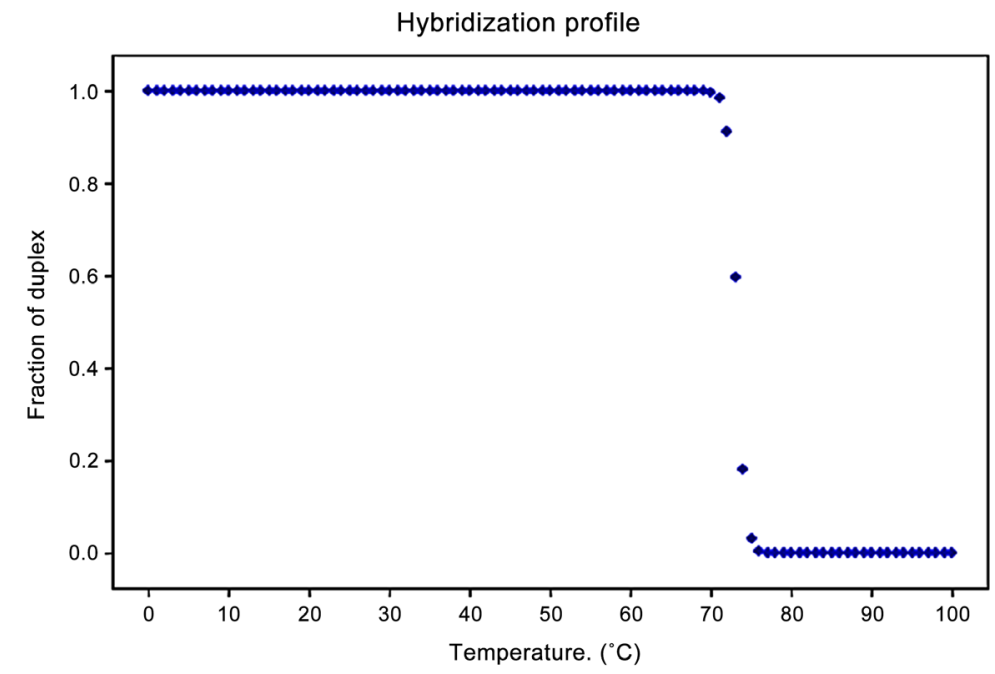

Figure 7. Hybridization profile of the Oligo DNA used as internal control. The total DNA is intact up to $70^{\circ} \mathrm{C}$, and the $\mathrm{T}_{\mathrm{m} 50 \%}$ is $73^{\circ} \mathrm{C}$.
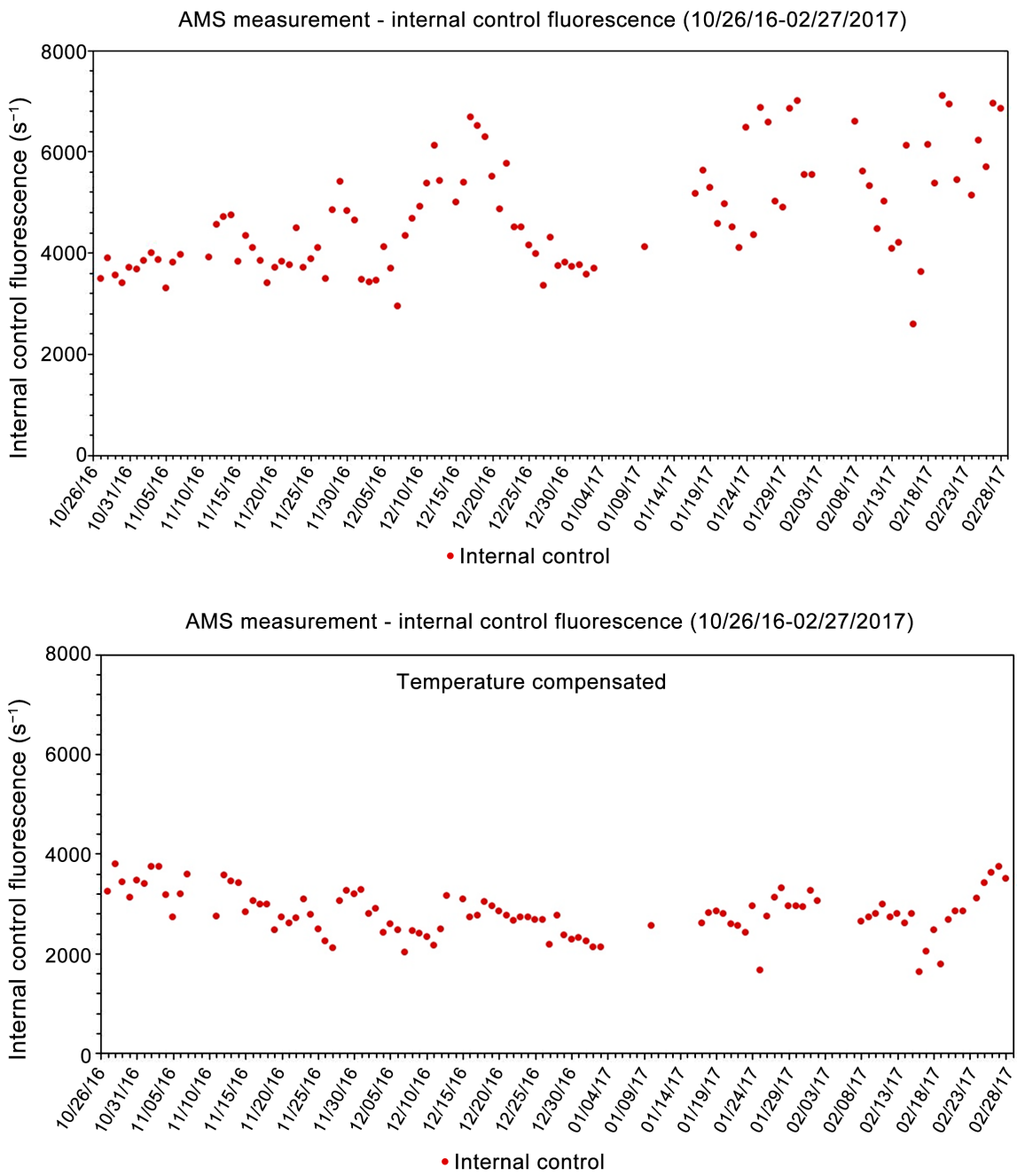

Figure 8. AMS1 autonomous sampling and measurement for fluorescence signals of IC DNA from October 2016 to February 2017-raw (top) and temperature compensated (bottom). 

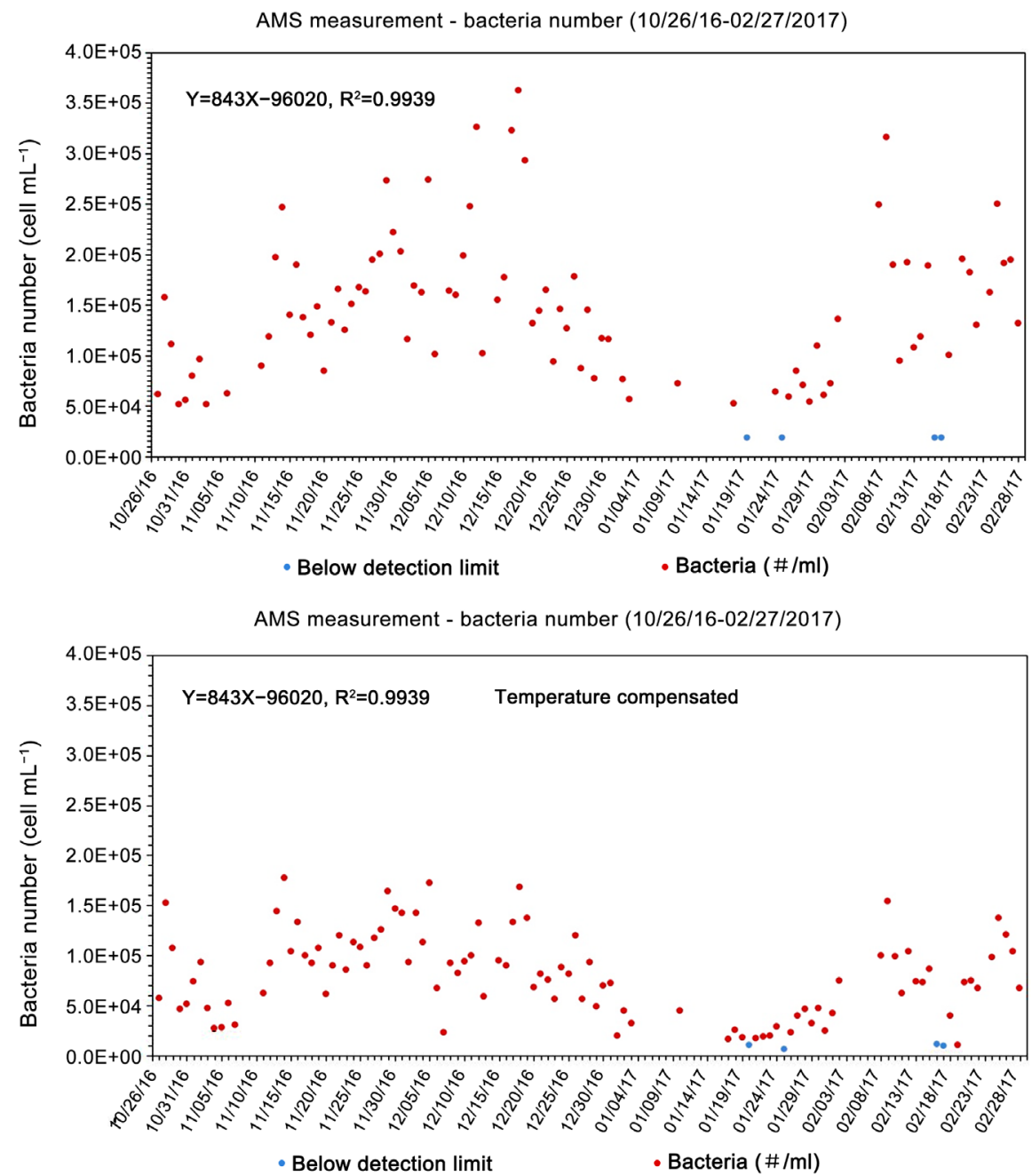

Figure 9. AMS1 autonomous sampling and measurement for microbial cell number from October 2016 to February 2017-raw (top) and temperature compensated (bottom).

another pressure regulator is installed on the side-stream to reduce the pressure to about 10 bars for prevention of damage to AMS hardware. Due to the harsh conditions in the seawater environment, the needle type pressure regulator tends to be easily clogged. To avoid clogging, the ball valve type or spring type pressure regulator is required for both side-stream and AMS. After the right type of pressure regulator is selected and installed, the regulator clogging and potential AMS damage due to high pressure are eliminated.

AMS liquid handling system consists of two syringe pumps, two multi-channel valves, and many tubings to transport various liquids around the AMS system for measurement, cleaning, and disposal. Loose fittings, wear and tear, and corrosion have been noticed during long-term field trials. Replacement of original Delrin fittings with PEEK fittings has solved the corrosion problem caused by oxalic acid and reduced the leaking occurrence. Occasional tightening and close monitoring of the fittings are required when there is large ambient temperature fluctuation. For AMS field deployment, an air conditioned (AC) shelter is recommended to maintain a relatively stable temperature in AMS 
Table 6. Lessons learned from field test of the AMS

\begin{tabular}{|c|c|c|c|}
\hline Element name & Issue & Lessons Learned & Action Required \\
\hline \multicolumn{4}{|c|}{ Reagents and solutions } \\
\hline SYBR dye & $\begin{array}{l}\text { Experienced inaccurate } \\
\text { volume of dye } \\
\text { collected by syringe. }\end{array}$ & $\begin{array}{l}\text { Solvent DMSO in } \\
\text { the dye will freeze } \\
\text { below } 12^{\circ} \mathrm{C} \text {. }\end{array}$ & $\begin{array}{l}\text { Consider insulating SYBR } \\
\text { vial or enclosing AMS } \\
\text { modules within an air } \\
\text { conditioned shelter. }\end{array}$ \\
\hline \multicolumn{4}{|c|}{ Reaction and measuring system } \\
\hline Flow cell & $\begin{array}{l}\text { Biocide entering } \\
\text { flow cell. }\end{array}$ & $\begin{array}{l}\text { Need to coordinate } \\
\text { with corrosion } \\
\text { engineer for biocide } \\
\text { injection time. }\end{array}$ & $\begin{array}{l}\text { Programmed AMS } \\
\text { measurement time } \\
\text { around the estimated } \\
\text { biocide arrival time. }\end{array}$ \\
\hline \multicolumn{4}{|c|}{ Liquid handling system } \\
\hline $\begin{array}{l}\text { Pressure } \\
\text { regulator }\end{array}$ & $\begin{array}{l}\text { Experienced clogging } \\
\text { of pressure regulator } \\
\text { inside AMS. }\end{array}$ & $\begin{array}{l}\text { Select right type of } \\
\text { regulator. }\end{array}$ & $\begin{array}{l}\text { Replaced original needle } \\
\text { type pressure regulator } \\
\text { with a ball valve to reduce } \\
\text { the pressure. Increased } \\
\text { sampling tubing size } \\
\text { from } 1 / 8^{\prime \prime} \text { to } 6 \mathrm{~mm} \text {. }\end{array}$ \\
\hline $\begin{array}{l}\text { Pressure } \\
\text { regulator }\end{array}$ & $\begin{array}{l}\text { Experienced damage } \\
\text { of pressure regulator } \\
\text { inside AMS. }\end{array}$ & $\begin{array}{l}\text { Avoid overpressure } \\
\text { of side-stream. }\end{array}$ & $\begin{array}{l}\text { Installed a pressure regulator } \\
\text { on side-stream to reduce the } \\
\text { pressure to below } 10 \text { bars } \\
\text { before connecting side-stream } \\
\text { to AMS. Installed a restrictor } \\
\text { with a pressure gauge to } \\
\text { monitor inlet pressure. }\end{array}$ \\
\hline Corrosion & $\begin{array}{l}\text { Experienced corrosion } \\
\text { of fittings. }\end{array}$ & $\begin{array}{l}\text { Delrin fittings is } \\
\text { prone to oxalic } \\
\text { acid corrosion. }\end{array}$ & $\begin{array}{l}\text { Replaced all Delrin fittings } \\
\text { with PEEK fittings. }\end{array}$ \\
\hline Leakage & $\begin{array}{l}\text { Experienced leakage } \\
\text { and precipitates } \\
\text { around fittings. }\end{array}$ & $\begin{array}{l}\text { Loosening of fittings } \\
\text { due to large } \\
\text { temperature } \\
\text { fluctuation. }\end{array}$ & $\begin{array}{l}\text { Equipped all fittings with } \\
\text { lock nut. Tighten fittings, } \\
\text { if necessary. }\end{array}$ \\
\hline \multicolumn{4}{|c|}{ Electronics and power system } \\
\hline Solar panel & $\begin{array}{l}\text { Experienced lots of } \\
\text { dust collection on } \\
\text { solar panels. }\end{array}$ & $\begin{array}{l}\text { Required monthly } \\
\text { cleaning. }\end{array}$ & $\begin{array}{c}\text { Consider installing solar panels at } \\
\text { proper height for easy access } \\
\text { during monthly maintenance. }\end{array}$ \\
\hline Power socket & $\begin{array}{l}\text { Power socket is not } \\
\text { water proof. }\end{array}$ & $\begin{array}{l}\text { Risk of water splash } \\
\text { entering power socket. }\end{array}$ & $\begin{array}{l}\text { Replaced power socket with } \\
\text { built-in power cable. }\end{array}$ \\
\hline
\end{tabular}

modules, which will have many beneficial effects: eliminate fitting loosening due to large temperature change, prevent SYBR Green dye freezing, prevent temperature-regulated AMS shutdown, and extend the life span of the AMS device.

In general, pre-industrial AMS sampling, conditioning, measurement sequence and method, solution and reagent refilling were found suitable for field application. When in operation, the AMS was subjected to routine maintenance from the operation manual (Table 7). 
Table 7. Pre-industrial AMS routine maintenance schedule.

\begin{tabular}{cl}
\hline Maintenance items & Schedule \\
\hline Check instrument inlet pressure & Monthly \\
Check instrument sample flow rate & Monthly \\
Inspect internal sample leak and blockage & Monthly \\
Clean solar panels & Monthly \\
Refill solutions and reagents & Monthly \\
Inspect tubings and fittings, and replace if necessary & Half-year service \\
Validate performance and recalibrate if necessary & Half-year service \\
\hline
\end{tabular}

\section{Conclusion and Recommendations}

The online AMS, based on fluorescent DNA staining technology, is developed in three phases for real-time detection of microbial cell numbers in large seawater injection systems under Saudi Arabian conditions. Numerous technical improvements have been implemented in each developmental phase for increased sensitivity, durability, robustness, and maintainability, while reducing the uncertainties related to AMS operation and function. Two pre-industrial AMS units have been constructed and deployed at critical field locations for automated monitoring of microbial numbers in injection seawater system (salinity 5.5\%). The two units are currently operational, including the hot summer months in Saudi Arabia without AC shelters, requiring only minimal monthly intervention from field operators and engineers. The wider deployment at more strategic locations in large Saudi Aramco sea water injection network is planned. In addition, a renewed market study is on-going to assess the market opportunities, technology landscape, and commercialization strategy.

For long-term reliability and maintainability, it is recommended to house the AMS hardware and solution modules inside an AC shelter. AC shelter is expected to provide two major benefits. One is to prevent solvent DMSO of SYBR Green dye from freezing when temperature in Saudi Arabia winter drops to below $12^{\circ} \mathrm{C}$. DMSO freezing affects the delivery of SYBR Green dye for bacteria staining, and hence the fluorescence signals. For hardware protection, AMS is programmed to shut down automatically when temperature is above $40^{\circ} \mathrm{C}$, resulting in many missing measurements during hot Saudi Arabia summer. An AC shelter increases the flexibility of programming measurement time and frequency throughout the year. It is also recommended to use dual power supply (mains power and solar panel) for battery charge, whenever mains power is available at the installation site. This will ensure the sufficient battery charge to power AMS operation in case of reduced solar panel efficiency caused by adverse weather and environmental conditions (e.g., rain, clouds, dust, and sand storms). The cleaning of solar panels should be maintained even when the mains power is connected.

Calibration is sensitive to the specific water system in question, therefore spe- 
cific calibration shall be performed during commissioning of each water system, to ensure the accurate conversion of fluorescence count to cell number in the sample. In addition, the performance of the AMS shall be validated after major maintenance and service, and re-calibrated if necessary.

\section{Acknowledgments}

The authors would like to acknowledge the Saudi Arabian Oil Company (Saudi Aramco) and the Danish Technological Institute for granting permission to publish this paper.

\section{References}

[1] Ren, H., Wang, W., Liu, Y., Liu, S., Lou, L., Cheng, D., He, X., Zhou, X., Qiu, S., Fu, L., Liu, J. and Hu, B. (2015) Pyrosequencing Analysis of Bacterial Communities in Biofilms from Different Pipe Materials in a City Drinking Water Distribution System of East China. Applied Microbiology and Biotechnology, 99, 10713-10724. https://doi.org/10.1007/s00253-015-6885-6

[2] Moniee, M.A., Juhler, S., Sørensen, K., Abeedi, F.N., Lundgaard, T. and Sanders, P.F. (2014) A Review of Saudi Aramco's Water Flooding System and Methods for Monitoring Microbial Activity. Proceedings 15th Middle East Corrosion Conference, Bahrain, 2-5 February 2014, 1-19.

[3] Moniee, M.A., Juhler, S., Sørensen, K., Zhu, X.Y., Lundgaard, T., Abeedi, F.N. and Sanders, P.F. (2016) Laboratory-Scale Evaluation of Single Analyte Bacterial Monitoring Strategies in Water Injection Systems. Journal of Sensor Technology, 6, 11-26. https://doi.org/10.4236/jst.2016.62002

[4] Moniee, M.A., Zhu, X.Y., Tang, L., Juhler, S., Nuwaiser, F.I., Sanders, P.F. and Abeedi, F.N. (2016) Optimization of DNA Staining Technology for Development of Autonomous Microbe Sensor for Injection Seawater Systems. Journal of Sensor Technology, 6, 27-45. https://doi.org/10.4236/jst.2016.63003

[5] Moniee, M.A., Zhu, X.Y., Tang, L., Nuwaiser, F.I., Voigt, N.V., Sanders, P.F., Abeedi, F.N. and Habboubi, H.H. (2016) Validation of Autonomous Microbe Sensor Prototype for Monitoring of Microorganisms in Injection Seawater Systems. Journal of Sensor Technology, 6, 81-100. https://doi.org/10.4236/jst.2016.64007

[6] Dragan, A.I., Pavlovic, R., McGivney, J.B., Casas-Finet, J.R., Bishop, E.S., Strouse, R.J., Schenerman, M.A. and Geddes, C.D. (2012) SYBR Green I: Fluorescence Properties and Interaction with DNA. Journal of Fluorescence, 22, 1189-1199. https://doi.org/10.1007/s10895-012-1059-8

[7] Noble, R.T. and Fuhrman, J.A. (1998) Use of SYBR Green I for Rapid Epifluorescence Counts of Marine Viruses and Bacteria. Aquatic Microbial Ecology, 14 113-118. https://doi.org/10.3354/ame014113

[8] Shibata, A., Goto, Y., Saito, H., Kikuchi, T., Toda, T. and Taguchi, S. (2006) Comparison of SYBR Green I and SYBR Gold Stains for Enumerating Bacteria and Viruses by Epifluorescence Microscopy. Aquatic Microbial Ecology, 43, 223-231. https://doi.org/10.3354/ame043223

[9] Maruyama, A. and Sunamura, M. (2000) Simultaneous Direct Counting of Total and Specific Microbial Cells in Seawater, Using a Deep-Sea Microbe as Target. Applied Environmental Microbiology, 66, 2211-2215. https://doi.org/10.1128/AEM.66.5.2211-2215.2000 
[10] Kapuscinski, J. (1995) DAPI: A DNA-Specific Fluorescent Probe. Biotechnic \& Histochemistry, 70, 220-233. https://doi.org/10.3109/10520299509108199

[11] Tarnowski, B.I., Spinale, F.G. and Nicholson, J.H. (1991) DAPI as a Useful Stain for Nuclear Quantitation. Biotechnic \& Histochemistry, 66, 296-302. https://doi.org/10.3109/10520299109109990

[12] LabVIEW 2015, Version 15.0f2 (64-bit), National Instruments Corporation, Austin, Texas, US. http://www.ni.com/labview/

[13] Gasol, J.M., Zweifel, U.L., Peters, F., Fuhrman, J.A. and Hagstro, A. (1999) Significance of Size and Nucleic Acid Content Heterogeneity as Measured by Flow Cytometry in Natural Planktonic Bacteria. Applied Environmental Microbiology, 65, 4475-4483.

[14] Sgorbati, S., Barbesti, S., Citterio, S., Bestetti, G. and de Vecchi, R. (1996) Characterization of Number, DNA Content, Viability and Cell Size of Bacteria from Natural Environments using DAPI PI Dual Staining and Flow Cytometry, Minerva Biotechnology, 8, 9-15.

[15] Gasol, J.M., del Giorgio, P.A., Massana, R. and Duarte, C.M. (1995) Active versus Inactive Bacteria: Size-Dependence in a Coastal Marine Plankton Community, Marine Ecology Progress Series, 128, 91-97. https://doi.org/10.3354/meps128091

[16] Marie, D., Partensky, F., Jacquet, S. and Vaulot, D. (1997) Enumeration and Cell Cycle Analysis of Natural Populations of Marine Picoplankton by Flow Cytometry Using the Nucleic Acid Stain SYBR Green I. Applied Environmental Microbiology, 63, 186-193.

[17] Thermo Scientific, FITC and TRITC, Instructions. https://assets.thermofisher.com/TFS-Assets/LSG/manuals/MAN0011224_FITC_TR ITC_UG.pdf 